\title{
Inflammation and cancer interconnection; simply as we think
}

\author{
Ahmed M. Hussein ${ }^{1 *}$, Zeinab E. Darwish² and Omar H. Soliman ${ }^{3}$
}

*Correspondence: aattay1@gmail.com

CrossMark

FClick for updates

'Lecturer of Oral and Maxillofacial Pathology Department, Faculty of Oral and Dental Medicine, SVU, Qena, Egypt.
2Professor of Oral Pathology, Faculty of Dentistry, Alexandria University, Alexandria, Egypt.
${ }^{3}$ Lecturer of Oral Medicine, Oral Diagnosis and Periodontology Department, Faculty of Oral and Dental Medicine, SVU, Qena, Egypt.

\begin{abstract}
Microbiota variety is site specific depending on its location in the body and this diversity can get together with human health. At the last decades, inflammation is a primary protective response that sometimes goes away and becomes a main cofactor in the pathogenesis of numerous chronic human diseases, including malignant tumor. As well, microbes have the potency power to influence tumor growth and progression through a wide forms of routes; including alteration of tumor microenvironment, prolonged activation of inflammation, induction of genotoxic restraints and metabolism. In this review, we will set a general overview of inflammation has suspected to provide a major role in the pathogenesis and development of cancer as an important object for advanced cancer biology.
\end{abstract}

Keywords: Inflammation, Cancer,Cytokine, Tumorigenesis

\section{Introduction}

The human body shortly becomes inhabited by microorganisms soon at birth. Microbes colonize zones that are immediately exposed to the air and surroundings including the nostrils, oral cavity, skin, stomach as well as the gastrointestinal and urogenital tracts. There is a large variation in the bacterial composition of sites within each organ between individuals. This variability is influenced by genetics, diet, medications intake and other external environmental factors. Additionally, the immune system affects species and localization of microbiota through congregate regulation of immune tolerance and inflammation [1]. The neoplasm has its microenvironment and inflammation; represent one of the hallmark of cancer and affect therapeutic resistance. The tumor immune response is inactiveequilibrium between antitumor mechanisms which serve to loweringthecancer growth and the pro-tumor inflammatory response which raising the immune tolerance, cell survival and reproduction. Inflammatory mediators exert pleiotropic actions in the growth of cancer. On one hand, inflammation advocacy carcinogenesis, malignant transformation, tumor growth, invasion and metastatic spread; on other hand, inflam- mation can activate immune effect or mechanisms that might limit tumor proliferation [2].

Based on the presence of leukocytes in cancerous lesions, Virchow made the initial connection between inflammation and cancer by monitoring leukocytes in neoplastic tissues [3]. During the last decade that is clear evidence of underlying molecular mechanism has been obtained suggesting that inflammation plays an important role in tumorigenesis and that chronic inflammation raising cancer risk. More than $25 \%$ of all of human cancer are related to prolonged inflammation and to viral and bacterial infections. However, the action of inflammation is not restricted to its roleat tumor initiation and growth; inflammation can also be induced in growing tumor or as a response to anticancer therapy and cell death [4]. Table 1 provides an over view on inflammatory and pathogenic conditions that are considered to be associated with malignant transformation.

To know the role of inflammation in the development of cancer, it is important to understand what inflammation mean and how it give a share in physiological and pathological processes. Inflammation is portion of the complex biological response 
Table 1. Examples of Inflammatory Conditions that are Associated with Malignancy [4].

\begin{tabular}{|c|c|}
\hline Inflammation that causes insults or pathological conditions & Associated malignancy \\
\hline Silica, asbestos, smoking-associated silicosis and bronchitis & Lung carcinoma \\
\hline Pelvic inflammatory disease & Ovarian carcinoma \\
\hline Chronic indwelling urinary catheter & Bladder carcinoma \\
\hline $\begin{array}{l}\text { TRYP1 mutation-associated pancreatitis and alcoholism-associated } \\
\text { pancreatitis }\end{array}$ & Pancreatic carcinoma \\
\hline UV irradiation-associated skin inflammation & Melanoma \\
\hline Asbestos & Mesothelioma \\
\hline Bile acids & Cholangiosarcoma and colorectal carcinoma \\
\hline Gastric acid-associated Barrett's metaplasia and reflux oesophagitis & Oesophageal carcinoma \\
\hline Gall bladder stone-associated cholecystitis & Gall bladder carcinoma \\
\hline Lichen sclerosus (a skin condition) & Vulvar carcinoma \\
\hline Inflammatory bowel disease & Colorectal carcinoma \\
\hline $\begin{array}{l}\text { Hashimoto's thyroiditis (an autoimmune disease of the thyroid) and } \\
\text { Sjögren's syndrome (an autoimmune disease of exocrine glands) }\end{array}$ & Mucosa-associated lymphoid tissue lymphoma \\
\hline Gingivitis (inflammation of the gum tissue) and lichen planus & Oral squamous cell carcinoma \\
\hline Sialadenitis (inflammation of the salivary gland) & Salivary gland carcinoma \\
\hline
\end{tabular}

of body tissues to harmful exciters such as pathogens, dead cells or irritants and is a covering response involving immune cells,molecular mediators and blood capillaries [3]. The role of inflammation is to remove the initial cause of tissue injury, eliminate necrotic cells from the original injury and to initiate tissue repair. The traditional signs of inflammation responsesare swelling,heat, pain, redness and lack of function. Inflammation is a general response that is theorized as a mechanism of innate immunity, as compared to adaptive immunity; which is special for each pathogen. Minor inflammation could lead to advanced tissue damage by the harmful stimulus (e.g. bacteria) and disclose the survival of the organism. In contrast, prolonged inflammation may result in a host of diseases likechronic rheumatoid arthritis, atherosclerosis, chronic periodontitis and even malignancy (e.g. gallbladder carcinoma). Therefore, inflammation is normally carefullyadjusted by the human body [5].

Inflammation can be classified as either acute or chronic. Acute inflammation is the earlyrestraint of the body to foreign stimuli and is achieved by the increased escape of plasma and leukocytes (especially granulocytes) from the blood capillariesinto the damaged tissues. A collection of biochemical events activates and matures the inflammatory response, involving theimmune system, the innate vascular system and numerous cells within the damaged tissue. Prolonged inflammation; recognize as chronic inflammation leads to anadvanced shift in the cells types present at the zone of inflammation and is characterized at the same timeby destruction and curing of the tissue from the inflammatory responses. The inflammatory response must be actively end when no longer needed to stop the unnecessary damage to tissues. Failure to do that; results in prolonged inflammation and tissuedamaged [6].

Varies types of inflammation differing by cause, mecha- nism, result and strength can promote cancer growth and development. Chronic inflammation associated with infections or autoimmune disease foregoes tumor growth and can contribute to it during induction of oncogenic mutations, genomic instability, initial tumor promotion and enhanced angiogenesis. Chronic exposure to environmental irritants can lead to low grade chronic inflammation that precedes tumor development [7]. Several type of cancers developed from sites of infection, chronic inflammation and irritation. It is becoming clear that the tumor microenvironment which is largely coordinated by inflammatory cells is a fundamental sharer in the neoplastic process, proliferation, survival and migration. In addition, cancer cells have some of the signaling molecules of the innate immune system such as chemokines, selectins and their receptors for infiltration, migration and metastasisspread. These ideas are fostering new anti-inflammatory therapeutic approaches to cancer growth and development [8]. Tumor associated inflammation goes together with cancer development. This inflammatory response can foster new angiogenesis, rise tumor progression and metastatic expansion cause innate immunosuppression and further genomic instability. Cancer treatments can also move to cause an inflammatory response by causing trauma, necrosis and tissue damaged that stimulate tumor recurrence and resistance to therapy. However, in some cases, treatment induced inflammation can promote antigen presentation result in immune mediated tumor enucleation [9] (Figure 1).

\section{Review \\ Inflammatory Cell Component of Tumors}

Tumor cells produce numerous cytokines and chemokines that catch leukocytes. The inflammatory responses of a developing tumor may include a different leukocyte category. As a result 


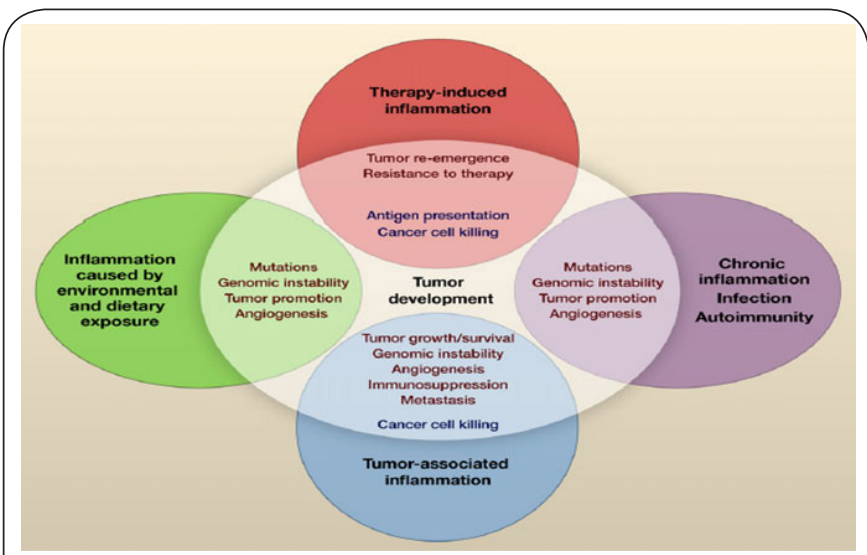

Figure 1. Types of Inflammation in Tumorigenesis and Cancer [9].

of these diversitytypes of inflammation, the cancer microenvironment has innate immune cells (including neutrophils, macrophages, dendritic cells, mast cells, myeloid-derived suppressor cells and natural killer cells) and adaptive immune cells ( $B$ and $T$ lymphocytes) in addition to the cancer cells and their embracing stroma which formed from fibroblasts, endothelial cells, pericytes and mesenchymal cells [10]. Table 2 summarized the role of most inflammatory cells in antitumor and tumor-promoting cancer.

\section{Pathways Connecting Inflammation and Cancer}

The interaction between tumorigenesis and inflammation is mediated through intrinsic and extrinsic pathways. The intrinsic pathway is achieved by genetic alterations result in inflammation and neoplasia. These variationsinclude mutation driven proto-oncogene activation, chromosomal rearrangement or amplification and inactivation of tumor suppressor genes. Transformed cells secrete inflammatory mediators and thus produce an inflammatory microenvironment. The extrinsic pathway is paid by inflammation or infections that rise the risk for the evolution of cancer in organs at risk such as the prostate, pancreas, colon, lung and skin [11]. The two pathways interfere in tumor cells and induce the activation of numerous transcription factors such as the nuclear factor (NF-KB), Signal transducer and activator of transcription 3 (STAT3), and Hypoxia-inducible factors (HIF-1) that lead to the formation of pro-inflammatory operatorsincluding chemokines, cytokines and Prostaglandin-end peroxide synthase 2 (PGHS-2). These molecules induct and activate various leukocyte populations such as macrophages, mast cells eosinophils and neutrophils into the tumor microenvironment like stromal and endothelial cells as well as infiltrating cells. This combined action of tumor and micro milieu results in a more pronounced generation of inflammatory mediators that drives the progression of appositive amplification loop which further triggers tumor infiltration and proliferation [12] (Figure 2).

\section{Impact of Inflammation in Tumorigenesis}

In the earlystage of tumor development; inflammatory mediators such as cytokines, reactive oxygen species (ROS) and reactive nitrogen species (RNS) obtained from tumor

Table 2. Roles of Different Subtypes of Immune and Inflammatory Cells in Antitumor Immunity and Tumor-Promoting Inflammation [9].

\begin{tabular}{|c|c|c|}
\hline Cell Types & Antitumor & Tumor-Promoting \\
\hline $\begin{array}{l}\text { Macrophages, dendritic cells, } \\
\text { myeloid-derived suppressor cells }\end{array}$ & $\begin{array}{l}\text { Antigen presentation; production of cytokines } \\
\text { (IL-12 and type I IFN) }\end{array}$ & $\begin{array}{l}\text { Immunosuppression; production of cytokines, } \\
\text { chemokines, proteases, growth factors, and } \\
\text { angiogenic factors }\end{array}$ \\
\hline Mast cells & & Production of cytokines \\
\hline$B$ cells & Production of tumor-specific antibodies? & $\begin{array}{l}\text { Production of cytokines and antibodies; } \\
\text { activation of mast cells; immunosuppression }\end{array}$ \\
\hline $\mathrm{CD}^{+} \mathrm{T}$ cells & $\begin{array}{l}\text { Direct lysis of cancer cells; production of } \\
\text { cytotoxic cytokines }\end{array}$ & Production of cytokines? \\
\hline $\mathrm{CD4}^{+} \mathrm{Th} 2$ cells & & $\begin{array}{l}\text { Education of macrophages; production of } \\
\text { cytokines; B cell activation }\end{array}$ \\
\hline $\mathrm{CD4}^{+}$Th1 cells & $\begin{array}{l}\text { Help to cytotoxic T lymphocytes (CTLS) in } \\
\text { tumor rejection; production of cytokines (IFNY) }\end{array}$ & Production of cytokines \\
\hline $\mathrm{CD4}^{+}$Th17 cells & Activation of CTLS & Production of cytokines \\
\hline $\mathrm{CD4}^{+}$Treg cells & $\begin{array}{l}\text { Suppression of inflammation (cytokines and } \\
\text { other suppressive mechanisms) }\end{array}$ & Immunosuppression; production of cytokines \\
\hline Natural killer cells & $\begin{array}{l}\text { Direct cytotoxicity toward cancer cells; } \\
\text { production of cytotoxic cytokines }\end{array}$ & \\
\hline Natural killer T cells & $\begin{array}{l}\text { Direct cytotoxicity toward cancer cells; } \\
\text { production of cytotoxic cytokines }\end{array}$ & \\
\hline Neutrophils & Direct cytotoxicity; regulation of CTL responses & Production of cytokines, proteases, and ROS \\
\hline
\end{tabular}


infiltrating immune cells produce epigenetic variation in pre-malignant lesions and silence tumor suppressor genes. During tumor promotion, immune cells excrete cytokines and chemokines that work as survival and proliferation factors for cancer cells. The angiogenic transition is critical for an enough supply of tumor cells with nutrition, oxygen, growth and survival factors. During tumor progression and metastasis, both tumor and immune cells produce cytokines and chemokines result in an increase in cell survival, motility and invasiveness [13] (Figure 3).

\section{Inflammation and Tumor Initiation}

In the process of tumor initiation; normal cells acquire the initial mutational multiply that sends them on the tumorigenic

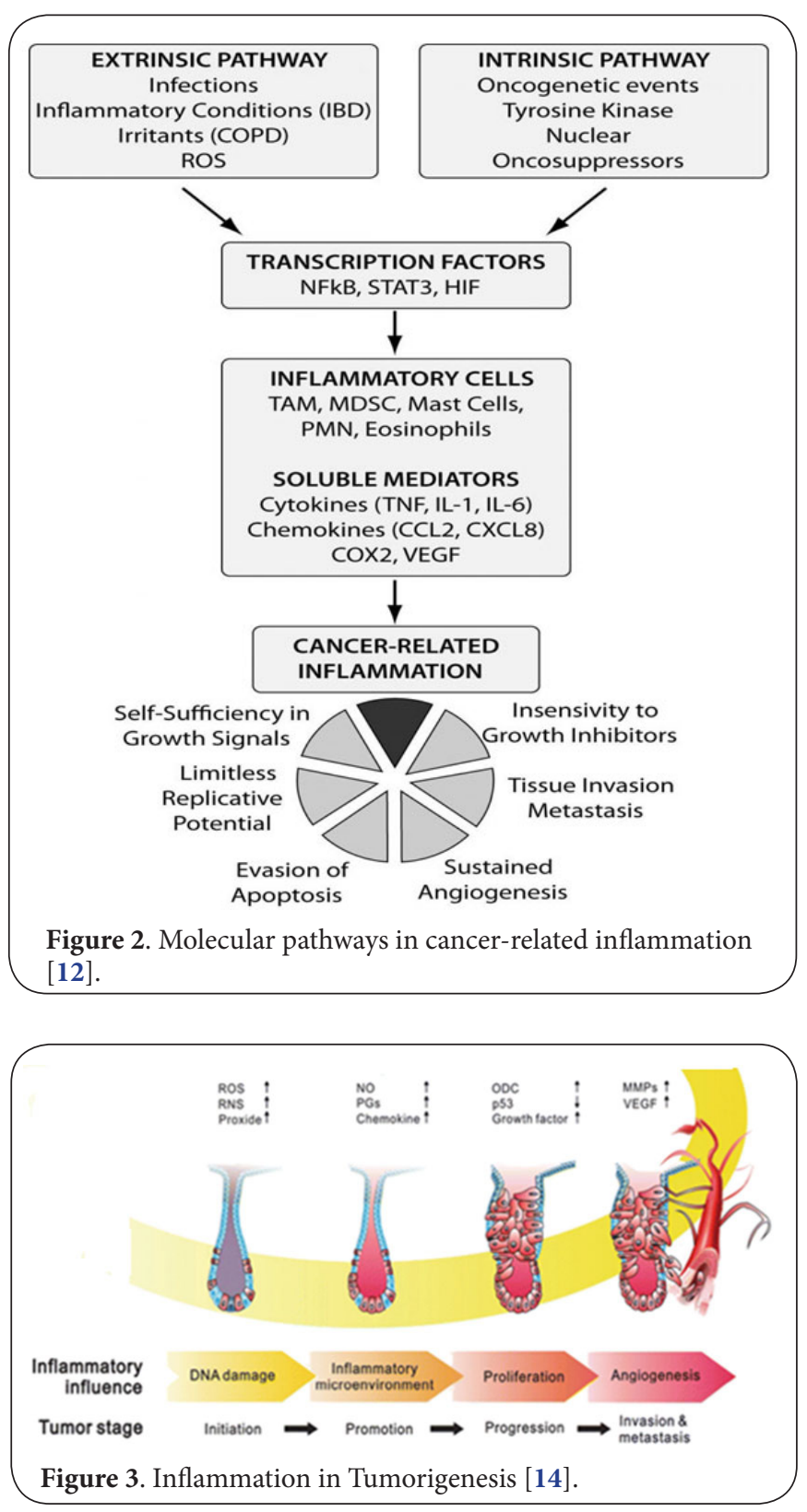

track by providing development and survival priority over their neighbors. In most cases, however, a single mutation is scanty and many cancers need at least 4 or 5 mutations; it has been approached that an inflammatory microenvironment can rise the mutation rates and activating the propagation of mutated cells. Activated inflammatory cells act as origins of ROS and RNS that are able toproducing DNA damage and genomic instability [15]. On the other hand, inflammatory cells may have cytokines like tumor necrosis factor (TNF-a) to stimulate ROS accumulation in adjoining epithelial cells. Inflammation produce mutagenesis may lead to inactivation or suppression of mismatch repair response genes, and ROS can also result in direct oxidative inactivation of mismatch repair enzymes [16]. Another mechanism linking inflammation with oncogenic mutations is up-regulation of activation produced cytidine deaminase (AID), an enzyme which promotes immunoglobulin gene class switching by catalyzing de-amination of DNA. The AID is overexpressed in many malignancies of diverse origins and its action is induced by inflammatory cytokines which produces genomic instability and rises mutation chance during error-prone ligature of double-stranded DNA breaks. Inflammation has been linked to epigenetic reprogramming which is encoded by an NF-kB target gene [17]. Other mechanism through which inflammation may activate tumor initiation is the induction of growth factors and cytokines that can allow a stem cell like phenotype upon tumor precursors or stimulate stem cell expansion, thereby connected to both stem cell reprogramming and stem cell renewal [18].

The interconnection between inflammation and cancer initiation is not a one-way street and there is also evidence that DNA damage can result in inflammation and thereby enhance tumorigenesis (Figure 4). One of the best examples is provided by the model of hepatocellular carcinoma induced by the carcinogen diethyl-nitrosamine, in which DNA damage contributes to necrotic cell death, resulting in an inflammatory action that activates tumor growth [19].

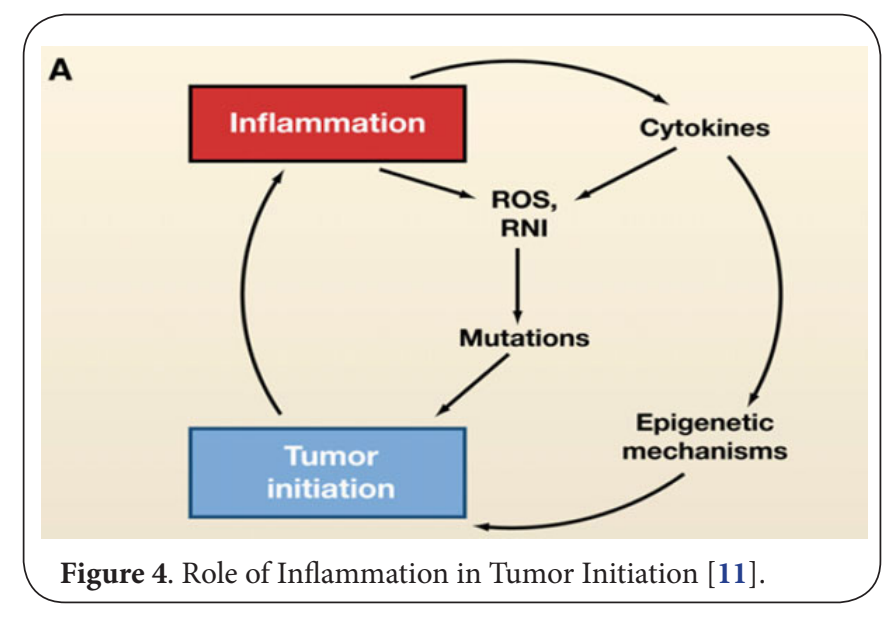




\section{Inflammation and Tumor Promotion}

Tumor promotion is the procedure of tumor development from a single initiated cell into a well-formed primary tumor. Earlycancer development depends on increased cell generation and decrease cell death, both of which are produced by inflammation driven actions. In verity, many of the inflammation activityon cancer are done at the level of tumor promotion and celebrated as tumor promoters' inflammation. Tumor promotion induced byinflammationmay occur early or late in cancer growth and can result in activation of premalignant conditions that were still for years. The strategies through which inflammation affects tumor promotion are variant and in addition to rise proliferation and allowsurvival can also involve the so known angiogenic switch, which promotea small dormant tumor to has the nutritionneedful for the next developmental phase [20]. Mechanisms of inflammation driven tumor promotion are discussed as following:

\section{A. Tumor-Promoting Cytokine Signaling}

Producing of tumor promoting cytokines by immune/inflammatory cells that promote transcription factors such as NF-kB, STAT3 and activator protein (AP-1) in premalignant tissues to produce genes that activate cell proliferation and survival is a main tumor promoting mechanism. The NF-kB and STAT3 activate genes that control cell survival, proliferation and development as well as angiogenesis, invasiveness, motility and chemokine/cytokine production [21]. Oncogenic transcription factors competencetoinducedpattern recognition receptors by complex of bacteria and viruses. Nonetheless, the action of the cytokines that are activated in response to danger-associated (DAMP) or pathogen-associated molecular mechanismsduringcancergrowth is more firmly established in raising the tumor promotion [22].

The numerous cytokines (IL-1, IL-6, IL-23, TNF) and transcription factors (AP-1, STAT3, NF-kB) are sensible for both inflammation and tumor development, they rulethe path of pro-tumorigenic signaling that may be aimed to limit both tumor associated inflammation and tumor development. Pharmacological intervention with cytokine signaling reduces tumorigenesis as well as tumor development and serve as a foundation for preventive and therapeutic approaches. Altogether, producing cytokine by immune and inflammatory cells is an important tumor promoting mechanism that allows malignant cells with a persistentproduction of growth and survival signals in a primary hostile microenvironment. In most cases, tumor promoting cytokines role in a paracrine mechanism, yet variantforms of cancer cells make their own cytokines, as IL-6 to have the same effect [23] (Figure 5).

\section{B. Inflammation and Angiogenesis}

Development of massive tumors needs an elevation of intratumoral blood feeding. This is triggered by tumor hypoxia, that induce angiogenesis and develop the ability of metastasisspread. Addition to hypoxia, cancer angiogenesis depends

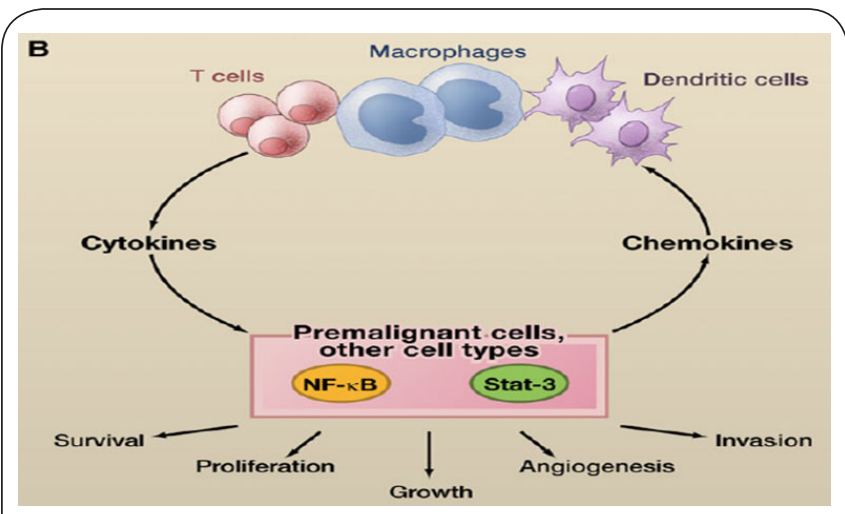

Figure 5. Role of Inflammation in Tumor Promotion [11].

on recruitment of tumor-associated macrophages (TAMs) which active hypoxic signals and in roleinduce chemokines and proangiogenic agents. Induction of TAMs precursors are largely client on angiogenic mediators like;angiopoietin-2 and vascular endothelial growth factor (VEGF). Production of new lymphatic vessels is organized by VEGF-C and VEGF-D, whereas VEGF-A allows the recruitment of monocytes, which produce lymphoangiogenesis. Also, VEGF-A produced by myeloid cells preventspericytes maturation and endothelial coverage of recently formed blood capillaries, and its surgical ablation activation tumorigenesis [24] (Figure 6).

As most developing tumors have some zones of hypoxia, there is not evident whether hypoxia is the mainoperator of tumor angiogenesis or whether hypoxic activateproducing inflammatory signals that induce angiogenesis. Inactivation of NF-kB or STAT3 or TAM depletion unequivocally results in disrupted angiogenesis and reduce tumor development that confirm the critical action of inflammatory mediators in cancer angiogenesis [25].

\section{Target Genes that Mediate Tumor Promotion}

Several of the genes that activate the tumor promoting func-

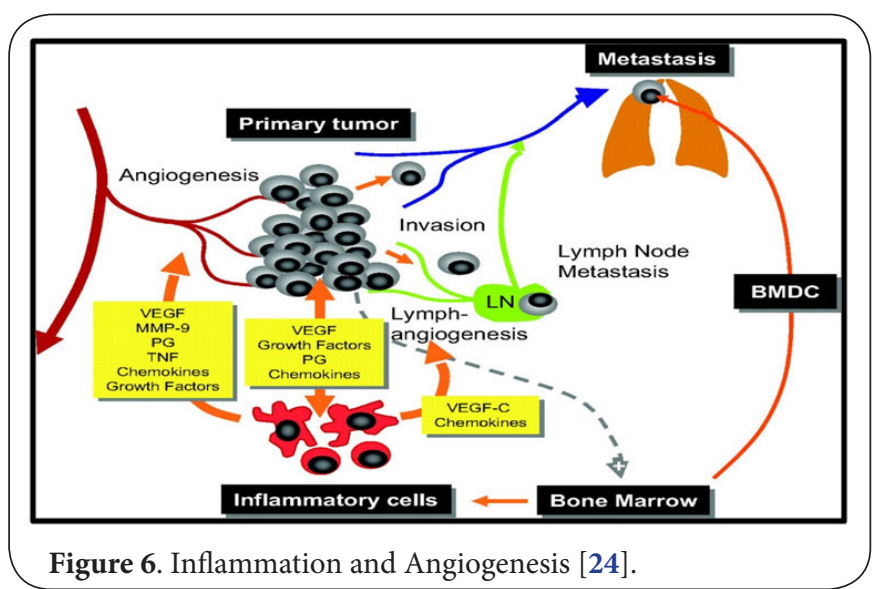


Hussein et al. Applied Scientific Reports 2020,

tions of NF-kB, STAT3 and AP-1 have not been whollyrealized, and most likely the pro-tumorigenic hints of these transcription factors are induced through different effectors. Some aims may be striped by more than one transcription factor and may be more important in one cell type than in another [26]. Another group of target genes which allow tumorigenesis are chemokines and cytokines that labor in autocrine or paracrine pattern to ensure the continuous needs of inflammatory cells into the cancer microenvironment. The persistence of chronic inflammation is mainly achieved through positive feedback loops, which include inflammatory cells producing cytokines that allow chemokine synthesis in malignant and stromal cells leading to chronic recruitment of inflammatory cells into the tumor microenvironment. In many cases, the definitive chemokines are not produced by malignant cells but are produced in tumor associated fibroblasts upon connection with malignant cells [27].

\section{Inflammation and Metastasis}

From a clinical aspect, metastasis is the most critical view of tumorigenesis, because more than $90 \%$ of malignant mortality is result from metastasis. Different searches show that metastasis needs close interactionbetween tumor cells, inflammatory and immunecells and stromal elements. The spread of cancer can be mainly divided into 4 major steps:

The first step is act by epithelial-mesenchymal transition (EMT), in which cancer cells have fibroblastoid features whichrise their motility and induce them to penetrate epithelial linings/basal membranes and invade the blood vessels or lymphatics [28]. In the second step, malignant cells intravasate through blood vessels and lymphatics. Inflammation may induce this through formation of mediators that allow vas cular permeability. This is followed by the third step, in which metastasis beginning cells survive and spread throughout the circulation. It has been estimated that nearly $0.01 \%$ of malignant cells that invade the circulation will finally survive and produce micro metastases. Finally, single metastatic progenitors interconnected with immune, inflammatory and stromal cells and beginning to proliferate. Many of these cells may formerly be acted to the pre-metastatic niche in restraint to tumor generated inflammatory signals before to the access of metastasis initiating malignant cells [25] (Figure 7).

The transforming growth factor (TGF- $\beta$ ) signaling is aseriousregulator of the EMT and metastasis, and elevated TGF- $\beta$ is mostlylinked to poor prognosis. In spite of the defects in TGF- $\beta$ signaling such tumors can as yet metastasize. These resistance effects of TGF- $\beta$ at variessteps of cancergrowth await mechanistic explanation. Malignant cell infiltrationneeds extreme proteolysis of the extracellular matrix at the invasive area. Inflammatory cells are effective provenance of proteases that degrade the extracellular matrix. Once metastatic cells reach the circulation they required to live in suspension and prevent detachment induced cell death. The survival of circulating malignant cells is influenced by inflammatory mediators

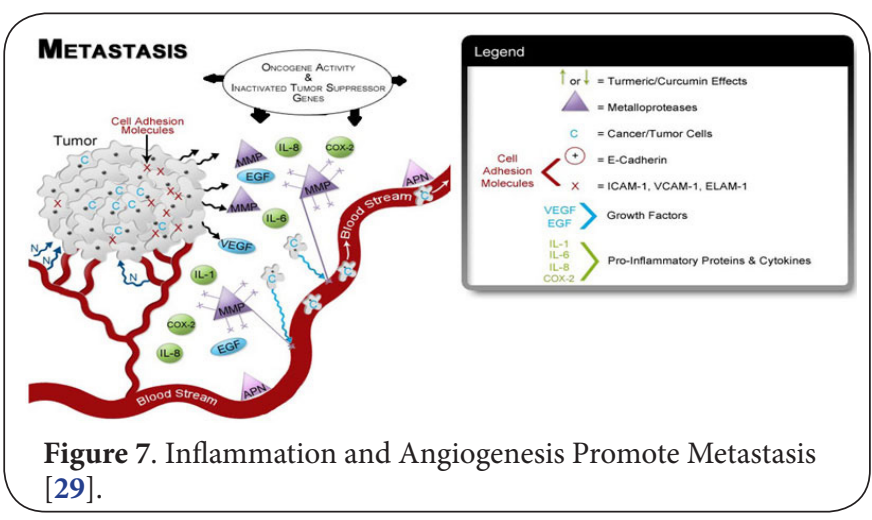

produced by immune cells in restraint to cancer derived or pathogen derived stimuli. In addition to NF-kB and STAT3 activation, numerous of these cytokines can physically connected cancer cells to TAMs, helping them to invade together throughout the circulation [30].

On other hand, single metastatic malignantcells, which are no longer sitting within an immunosuppressive area, may be aimed again by immunosurveillance. Exactly, in some cases, infiltration of tumors by activated T cells reduces the spread of metastasis. The connection of circulating malignant cells with platelets or macrophages may prevent them from NK cell-mediated killing, thereby overcoming immunosurveillance [31]. Systemic inflammation promotesconnection of circulating malignant cells to hepatic sinusoids, and this process is ruled by neutrophil-dependent upregulation of adhesion molecules. Several pro-inflammatory cytokines that are elevated in the circulation of cancer patient upregulate expression of adhesion molecules on the endothelium or in target organs and thereby rise the probability of metastatic cell attachment. Somematurefirm tumors contain infiltrates of diverse leukocyte subsets. Leukocyte complexity modify depending on the tissue or organ position and grades of malignancy [32], suggesting that immune based therapies will able to reflect these small difference and be more specialty.

\section{Cell Players and Mechanisms \\ Myeloid cells}

During homeostatic state, leukocytes are encumbrance with maintaining tissue health. Innate immune cells having macrophages, granulocytes, mast cells, dendritic cells, innate lymphocytes and natural killer cells, which represent the initialmechanism of defense versus pathogens and foreign bodies. In tumors, these facts miss to solve and therefore result inprolonged inflammation of the damaged neoplastic tissue. Chronically activated leukocytes provide direct and indirect growth factors that induce proliferation of malignant and stromal cells [33]. In addition, numerous leukocyte subsets predominantly macrophages, granulocytes, monocytes and mast cells producevariant classes of proteolytic enzymes that adjust the structure and function of extracellular matrix. So that 
their chronic presence allows a survival benefits to improve cancer cells by preserving proliferative signaling, decreasing cell death in restraint to matrix detachment, production and maintenance of angiogenesis, facilitating cancer cell escape and weaken antitumor cytotoxic cell mediated killing of cancer cells [34].

\section{$T$ cells}

The CD4+ T helper cells are the organizer of inflammatory procedure in tumor tissue. Anumerous T helper (TH) subsets (TH1 2, 9, 10, 17 and 22) specialized for activation particular types of inflammation, induction through their excretion of a restricted set of cytokines enabling responses immunityto tailored the special pathogen encountered. All of these distinct $\mathrm{CD} 4+\mathrm{T}$ cell types can give a share in tumorigenesis by different paths depending on context. For example, regulatory $\mathrm{T}$ immunosuppressive subset of TH cells prevent cytotoxic action of $C D 8+T$ cells through preventing tumor rejection [35]. Although in genericfavoring tumor refuse TH1 cells might contribute to tumor escape through secretion of interferon (IFN) $-\gamma$, which triggers expression of apoptosis ligand that provides off signals to cytotoxic T cells. Furthermore, selective evolutionary pressure by IFN- $\gamma$ may result in tumor editing and selection of resistant clones, thereby facilitating tumor growth [36].

The IL-17 induced by TH17 cells can act with IFN- $\gamma$ to allow secretion of the chemokines CXCL9 and CXCL10 by cancer cells which engage cytotoxic T cells. Such connectionactions of IL-17 and IFN- $\gamma$ could possibly be able to cancer treatment. The immune checkpoint molecules such as apoptotic protein PD-1 (a T cell receptor that mediates T cell inhibition) and its ligands, PD-L1 and PD-L2 forms a main receptor/ligand prevention pathway regulating $T$ cell responses. Expression of PD-L1 on surfaces of tumor cells and tumor infiltrating myeloid cells allow an off signal to PD-1-expressing T cells and thus induce tumor cells to escape immune-surveillance. Under continuous antigen exposure (such as in chronic infections or in tumor microenvironments) both CD4+ and CD8+ T cells upregulate PD-1 expression, contributing to T cell exhaustion. Blocking this pathway, such as, during prolonged viral infection, reinvigorates virus-specific CD8+T cell responses and results in enhanced $T$ cell effector responses and viral clearance. However, classical chemotherapy paradoxically rises the number of macrophages expressing PD-L1, through prevention CD8+ T cells and elevation the risk of therapy failure [37].

\section{B cells}

As the onlymaker of immunoglobulins, B cells are important for humoral immunity and also effect other leukocyte variant. For example, B cell induced paracrine factors can be causative and/or potentiate disease by sustaining chronic inflammation through autoimmunity [38]. The action of B cells in cancer is under greatresearch. In the skin, squamous carcinogenesis is restricted in the loss of $B$ cells. Two mechanisms implicated in B cell dependent skin carcinogenesis: (I) When autoantibody IgG is deposited via neoplastic parenchyma through leaky blood vessels ligation of immune complex/Fcy receptors on mast cells and macrophages fosters pro-angiogenic and immunosuppressive gene expression programs; (II) B cell secretion of IL-10 and TNFa activates pro-tumorigenic myeloid cells that allow foster cancer progression [39].

\section{COX -2}

The arachidonic acid (AA) cascade has a vital role in mediating either the suppression or production of the inflammatory response. The COX-2 is the initial regulatory enzymes responsible for the translation of AA into the several lipid mediators involved in many biological functions. COX-2 has noted tumorigenic advantages and contributes to carcinogenesis by allowing insensitivity to antigrowth hints, evasion of apoptosis, sustained angiogenesis and tissue invasion/ metastasis. Overexpression of COX-2 has been associated with carcinogenesis in animal models, and in several human cancers. The indirect action of the COX-2/PGE2 pathway in adjusting the tumor immune microenvironment has also been suggested via IL-17 promoting macrophage segregation [40].

\section{$N F-\kappa B$}

The NF-KB transcription factors are preserved as coordinating regulators of immune and inflammatory actions that have a vital role in oncogenesis. All NF-KB family are necessary for dimerization and binding to DNA elements. These dimers bind to inhibitory protein IKB family of proteins (inhibitors of NF-KB) stopping their binding to DNA domains and localizing them to the cytoplasm in most quiescent cells [41]. Furthermore, physical, physiological and/or oxidative stress lead to activation of innate immunological processes resulting in inflammation which is associated with activation of the NF-KB signaling pathway. The NF-KB has a twin effect on inflammation. On one hand, the activation of NF-KB, as portion of the acute immune response, activates cytotoxic immune cells against malignant cells [42]. However, the activation of NF-KB also lead to up-regulation of antiapoptotic genes and the induced expression of other pro-inflammatory cytokines (e.g., TNF- $a, \mathrm{IL}-1, \mathrm{IL}-6$ and IL-8) and adhesion molecules which result in the recruitment of leukocytes to the zone of inflammation. NF-KB activation is also engaged in growth regulation and contributes to tumor progression by controlling vascularization of tumors through upregulation of VEGF and its receptors. The activation of NF-KB causes an increase in expression of the transcription factor Snail, that is essential in the TNF-a-induction of EMT which enables tumor progression and metastasis [22].

\section{$T N F-\alpha$}

The TNF- $\alpha$ is a key pro-inflammatory cytokine, secreted by inflammatory cells which is involved in inflammation as- 
sociated carcinogenesis. It was named TNF-a due to it can produce tumor regression via the inducement of cell death. TNF-a is concerned in inflammation and immunity; as well as in a multitude of biological processes globalprogramed cell death, cell survival, angiogenesis and tumor cell invasion and migration [43]. The TNF-a tumor promoting action is depended on ROS and RNS which can produce DNA damage and allow tumorigenesis. Direct evidence also points to the action of TNF- $a$ in the metastatic cascade. Administration of TNF-a result in significant increase of the number of lung metastases. So, although TNF-a is a cytokine with recognized anticancer feature that has been applied as an anticancer agent for the therapy of some patients havingmassive solid tumors, its compact as a constituent within a multipronged approach targeted at a broad-spectrum of aims will need to be carefully assessed in light of these complicatedresults [44].

\section{iNOS}

Duringideal physiological conditions, nitric oxide synthases NOS is induced by the constitutive forms of NOS (cNOS/eNOS) and modulates vitalcellular processes such as vasodilatation, cell survival and development. However, in chronic inflammatory cases the iNOS-NO role is upregulated, and quickly yields; NO-derived species with strong nitrosative advantages especially when other reactive species are as will produced. Once formed, NO-derived species can quickly interact with all cellular structures including proteins, lipids and DNA. Therefore, the mostly carcinogenic role of NO-derived metabolites is related to their ability to potentiate genomic instability as stimulated by the RNS peroxynitrite [45]. In malignant tumor, NOS can be provided from both host and cancer cells; therefore, blocking tumor-iNOS hold potential implications for healthy cells. The method of therapeutic delivery needs a degree of specificity for malignant cells [46].

\section{AKT}

Protein kinases are an important house of regulatory enzymes needed for the development, division and proliferation of cells and they have been closely studied as possible mediators of oncogenesis. In particular, the kinase signaling pathway known as phosphatidylinositol 3-kinase/protein-kinase-B/ mammalian target of rapamycin represents one of the intracellular cascades of utmost importance when examining cellular proliferation, differentiation as well as cytoskeletal reorganization. The dysregulation of this pathway can direct the cell towards a carcinogenesis. As well, evidence indicated that AKT allows NF-KB activation [47].

\section{Chemokines}

Chemokines were originally had ability to adjust the directional migration of leukocytes to inflammatory sites. This observation has role for tumorigenesis as inflammatory cell infiltration is a common feature of numerous cancers and has varied functional consequences. Chemokines or chemotactic cytokines are a group of small (8-14 kDa) heparin-binding proteins that interact with cognate cell surface receptors and actserious roles in a varies of physiological processes such as growth, host immunity and cellular trafficking. These functionally related small secreted proteins constitute the largest cytokine group in humans [48].

In addition to their role in cell migration and inflammation, the chemokine/chemokine receptor system impacts development and progression of malignant diseases by regulating tumor initiation, growth, survival, migration, adhesion, invasion, angiogenesis and metastasis. Chemokines and their receptors regulate tumorigenesis directly by acting on tumor cells, and indirectly by regulating the composition of the inflammatory infiltrate. The diversity of the chemokine/chemokine receptor system is such that it can both contribute to, and inhibit, key events relevant to the tumorigenic process [49].

\section{Future Directions}

The variance between tissues in which inflammation clearly drives cancer development (such as the gastrointestinal tract, liver and lung) and organs that can has severe chronic inflammation that has no increased risk of malignancy (such as the joints in rheumatoid arthritis) may be in relation to the presence or function of commensal microbial populations. As well, regions that are characterized by intense epithelial-microbial interactions (such as the intestine, lung and the liver, which is constantly exposed to gut-derived microbial products) may show an inflammation induced tumor tendency that is distinct from tissues that feature near sterility (such as joints and the brain). Hence, the commensal microbiota may represent the hiddenconnection between inflammatory preconditioning and the danger of tumor development. Not all chronic inflammatory diseases rise the risk of cancer; on the contrary many of them such as psoriasis have been associated with a decrease incidence of cancer [50]. Furthermore, the microorganisms can influence the inflammatory processes that are associated with cancer development may lead a new phase in the treatment of cancer. In the future, the targeted elimination of cancer-associated microorganisms might provide a new therapy option which, if effective, seems very attractive because of its minimal expected side effects and the possibility of its preventive application.

\section{Conclousion}

The concept of inflammation enhance cancer has been firmly established during the last decade but many of the pathwaysthat connect inflammatory processes to their considerable modulatory effects on various stages of tumor development remain elusive. The great link between tumor cells and their inflammatory microenvironment have been specified and we have learned a mainsearch about the cell types and mechanisms that are implicated in the interplay of inflammation, genetic instability, neoplasia and chemotherapy. Nonetheless, fundamental questions remain to be answered 
Hussein et al. Applied Scientific Reports 2020,

and this limits our ability to deed the growing knowledge of cancer associated inflammation for the development of recent therapeutic approaches.

\section{Competing interests}

The authors declare that they have no competing interests.

Authors' contributions

\begin{tabular}{|l|c|c|c|}
\hline Authors' contributions & AMH & ZED & OHS \\
\hline Research concept and design & $\checkmark$ & $\checkmark$ & -- \\
\hline Collection and/or assembly of data & $\checkmark$ & -- & $\checkmark$ \\
\hline Data analysis and interpretation & $\checkmark$ & -- & $\checkmark$ \\
\hline Writing the article & $\checkmark$ & $\checkmark$ & -- \\
\hline Critical revision of the article & $\checkmark$ & -- & $\checkmark$ \\
\hline Final approval of article & $\checkmark$ & -- & -- \\
\hline Statistical analysis & $\checkmark$ & $\checkmark$ & -- \\
\hline
\end{tabular}

Publication history

EIC: Hikmet Budak, Sabanci University, Turkey.

Received: 12-Dec-2019 Final Revised: 17-Feb-2020

Accepted: 27-Feb-2020 Published: 09-Mar-2020

\section{References}

1. Francescone R, Hou V and Grivennikov SI. Microbiome, inflammation, and cancer. Cancer J. 2014; 20:181-9. | Article | PubMed Abstract | PubMed FullText

2. Hanahan D and Weinberg RA. Hallmarks of cancer: the next generation. Cell. 2011; 144:646-74. | Article | PubMed

3. Virchow R. An Address on the Value of Pathological Experiments. $\mathrm{Br}$ Med J. 1881; 2:198-203. I Article I PubMed Abstract I PubMed FullText

4. Elinav $E$, Nowarski $R$, Thaiss $C A$, Hu B, Jin $C$ and Flavell RA. Inflammationinduced cancer: crosstalk between tumours, immune cells and microorganisms. Nat Rev Cancer. 2013; 13:759-71. | Article | PubMed

5. Ungefroren $H$, Sebens $S$, Seidl $D$, Lehnert $H$ and Hass R. Interaction of tumor cells with the microenvironment. Cell Commun Signal. 2011; 9:18. | Article | PubMed Abstract | PubMed FullText

6. Headland SE and Norling LV. The resolution of inflammation: Principles and challenges. Semin Immunol. 2015; 27:149-60. I Article I PubMed

7. Berraondo P, Minute L, Ajona D, Corrales L, Melero I and Pio R. Innate immune mediators in cancer: between defense and resistance. Immunol Rev. 2016; 274:290-306. | Article | PubMed

8. Coussens LM and Werb Z. Inflammation and cancer. Nature. 2002; 420:860-7. | Article | PubMed Abstract | PubMed FullText

9. Grivennikov SI, Greten FR and Karin M. Immunity, inflammation, and cancer. Cell. 2010; 140:883-99. | Article | PubMed Abstract | PubMed FullText

10. Roy S and Zhuang Y. Paradoxical role of Id proteins in regulating tumorigenic potential of lymphoid cells. Front Med. 2018; 12:374-386. I Article I PubMed

11. Coussens LM, Zitvogel L and Palucka AK. Neutralizing tumor-promoting chronic inflammation: a magic bullet? Science. 2013; 339:286-91. | Article | PubMed Abstract | PubMed FullText

12. Del Prete A, Allavena P, Santoro G, Fumarulo R, Corsi MM and Mantovani A. Molecular pathways in cancer-related inflammation. Biochem Med (Zagreb). 2011; 21:264-75. | Article | PubMed

13. Grivennikov SI and Karin M. Inflammation and oncogenesis: a vicious connection. Curr Opin Genet Dev. 2010; 20:65-71. | Article I PubMed Abstract I PubMed FullText

14. Pan MH, Lai CS and Ho CT. Anti-inflammatory activity of natural dietary flavonoids. Food Funct. 2010; 1:15-31. | Article | PubMed
15. Hanahan D and Weinberg RA. The hallmarks of cancer. Cell. 2000; 100:57-70. | Article I PubMed

16. Colotta F, Allavena P, Sica A, Garlanda C and Mantovani A. Cancerrelated inflammation, the seventh hallmark of cancer: links to genetic instability. Carcinogenesis. 2009; 30:1073-81. | Article | PubMed

17. Okazaki IM, Kotani A and Honjo T. Role of AID in tumorigenesis. Adv Immunol. 2007; 94:245-73. | Article | PubMed

18. Harricharran T and Ogunwobi OO. Emergence of neural regulatory mechanisms in carcinogenesis. World J Clin Oncol. 2019; 10:279-282. I Article | PubMed Abstract | PubMed FullText

19. Pang Y, Li H, Gong Y, Jing S, Peng C, Liu W, Zhao Y, Wang H, Kaushik D, Rodriguez R and Wang Z. Association of CCL2, CCR2 and CCL5 genetic polymorphisms with the development and progression of benign prostatic hyperplasia. Oncol Rep. 2019; 41:2491-2501. | Article | PubMed

20. Carron EC, Homra S, Rosenberg J, Coffelt SB, Kittrell F, Zhang Y, Creighton CJ, Fuqua SA, Medina D and Machado HL. Macrophages promote the progression of premalignant mammary lesions to invasive cancer. Oncotarget. 2017; 8:50731-50746. | Article | PubMed Abstract | PubMed FullText

21. Feng Z, Yang R, Wu L, Tang S, Wei B, Guo L, He L and Feng Y. Atractylodes macrocephala polysaccharides regulate the innate immunity of colorectal cancer cells by modulating the TLR4 signaling pathway. Onco Targets Ther. 2019; 12:7111-7121. | Article | PubMed Abstract | PubMed FullText

22. Waters JP, Pober JS and Bradley JR. Tumor necrosis factor and cancer. J Pathol. 2013; 230:241-8.

23. Zou JM, Qin J, Li YC, Wang Y, Li D, Shu Y, Luo C, Wang SS, Chi G, Guo F, Zhang GM and Feng ZH. IL-35 induces N2 phenotype of neutrophils to promote tumor growth. Oncotarget. 2017; 8:33501-33514. | Article | PubMed Abstract | PubMed FullText

24. Shojaei F, Wu X, Malik AK, Zhong C, Baldwin ME, Schanz S, Fuh G, Gerber $\mathrm{HP}$ and Ferrara N. Tumor refractoriness to anti-VEGF treatment is mediated by CD11b+Gr1+ myeloid cells. Nat Biotechnol. 2007; 25:91120. | Article I PubMed

25. Cheng Y, Lu Y, Zhang D, Lian S, Liang H, Ye Y, Xie R, Li S, Chen J, Xue X, Xie J and Jia L. Metastatic cancer cells compensate for low energy supplies in hostile microenvironments with bioenergetic adaptation and metabolic reprogramming. Int J Oncol. 2018; 53:2590-2604. I Article I PubMed

26. Wang $Y$, Shen $Y$, Wang S, Shen $Q$ and Zhou $X$. The role of STAT3 in leading the crosstalk between human cancers and the immune system. Cancer Lett. 2018; 415:117-128. | Article | PubMed Abstract | PubMed FullText

27. Schinagl A, Thiele M, Douillard P, Volkel D, Kenner L, Kazemi Z, Freissmuth $M$, Scheiflinger $F$ and Kerschbaumer RJ. Oxidized macrophage migration inhibitory factor is a potential new tissue marker and drug target in cancer. Oncotarget. 2016; 7:73486-73496. | Article | PubMed Abstract | PubMed FullText

28. Kalluri R and Weinberg RA. The basics of epithelial-mesenchymal transition. J Clin Invest. 2009; 119:1420-8. | Article | PubMed Abstract | PubMed FullText

29. Kaplan RN, Riba RD, Zacharoulis S, Bramley AH, Vincent L, Costa C, MacDonald DD, Jin DK, Shido K, Kerns SA, Zhu Z, Hicklin D, Wu Y, Port JL, Altorki N, Port ER, Ruggero D, Shmelkov SV, Jensen KK, Rafii S and Lyden D. VEGFR1-positive haematopoietic bone marrow progenitors initiate the pre-metastatic niche. Nature. 2005; 438:820-7. I Article I PubMed Abstract | PubMed FullText

30. Condeelis J and Pollard JW. Macrophages: obligate partners for tumor cell migration, invasion, and metastasis. Cell. 2006; 124:263-6. | Article I PubMed

31. Zhao X, Fan W, Xu Z, Chen H, He Y, Yang G, Hu H, Tang S, Wang P, Zhang $\mathrm{Z}, \mathrm{Xu} \mathrm{P}$ and $\mathrm{Yu} \mathrm{M}$. Inhibiting tumor necrosis factor-alpha diminishes desmoplasia and inflammation to overcome chemoresistance in pancreatic ductal adenocarcinoma. Oncotarget. 2016; 7:81110-81122. | Article I PubMed Abstract I PubMed FullText

32. Nakamura $\mathrm{K}$ and Smyth MJ. Targeting cancer-related inflammation in the era of immunotherapy. Immunol Cell Biol. 2017; 95:325-332. | Article | PubMed 
Hussein et al. Applied Scientific Reports 2020,

33. Lu P, Takai K, Weaver VM and Werb Z. Extracellular matrix degradation and remodeling in development and disease. Cold Spring Harb Perspect Biol. 2011; 3. | Article | PubMed Abstract | PubMed FullText

34. Schulz M, Salamero-Boix A, Niesel K, Alekseeva T and Sevenich L. Microenvironmental Regulation of Tumor Progression and Therapeutic Response in Brain Metastasis. Front Immunol. 2019; 10:1713. | Article | PubMed Abstract | PubMed FullText

35. Jia XH, Feng GW, Wang ZL, Du Y, Shen C, Hui H, Peng D, Li ZJ, Kong DL and Tian J. Activation of mesenchymal stem cells by macrophages promotes tumor progression through immune suppressive effects. Oncotarget. 2016; 7:20934-44. | Article | PubMed Abstract | PubMed FullText

36. Matsushita H, Vesely MD, Koboldt DC, Rickert CG, Uppaluri R, Magrini VJ, Arthur CD, White JM, Chen YS, Shea LK, Hundal J, WendI MC, Demeter R, Wylie T, Allison JP, Smyth MJ, Old LJ, Mardis ER and Schreiber RD. Cancer exome analysis reveals a T-cell-dependent mechanism of cancer immunoediting. Nature. 2012; 482:400-4. | Article | PubMed Abstract | PubMed FullText

37. Sakthivel P, Gereke M and Bruder D. Therapeutic intervention in cancer and chronic viral infections: antibody mediated manipulation of PD-1/ PD-L1 interaction. Rev Recent Clin Trials. 2012; 7:10-23. | Article | PubMed

38. de Visser KE, Korets LV and Coussens LM. De novo carcinogenesis promoted by chronic inflammation is B lymphocyte dependent. Cancer Cell. 2005; 7:411-23. | Article | PubMed

39. Schioppa T, Moore R, Thompson RG, Rosser EC, Kulbe H, Nedospasov S, Mauri $C$, Coussens LM and Balkwill FR. B regulatory cells and the tumorpromoting actions of TNF-alpha during squamous carcinogenesis. Proc Natl Acad Sci U S A. 2011; 108:10662-7. | Article | PubMed Abstract | PubMed FullText

40. Li Q, Liu L, Zhang Q, Liu S, Ge D and You Z. Interleukin-17 Indirectly Promotes M2 Macrophage Differentiation through Stimulation of COX2/PGE2 Pathway in the Cancer Cells. Cancer Res Treat. 2014; 46:297306. | Article | PubMed Abstract | PubMed FullText

41. Ben-Neriah $Y$ and Karin M. Inflammation meets cancer, with NF-kappaB as the matchmaker. Nat Immunol. 2011; 12:715-23. I Article I PubMed

42. Laveti D, Kumar M, Hemalatha R, Sistla R, Naidu VG, Talla V, Verma $\mathrm{V}$, Kaur $\mathrm{N}$ and Nagpal R. Anti-inflammatory treatments for chronic diseases: a review. Inflamm Allergy Drug Targets. 2013; 12:349-61. I Article | PubMed

43. Balkwill F. TNF-alpha in promotion and progression of cancer. Cancer Metastasis Rev. 2006; 25:409-16. | Article | PubMed

44. Allen H, Shraga-Heled N, Blumenfeld M, Dego-Ashto T, Fuchs-Telem D, Gilert A, Aberman Z and Ofir R. Human Placental-Derived Adherent Stromal Cells Co-Induced with TNF-alpha and IFN-gamma Inhibit TripleNegative Breast Cancer in Nude Mouse Xenograft Models. Sci Rep. 2018; 8:670. | Article | PubMed Abstract | PubMed FullText

45. Cheng H, Wang L, Mollica M, Re AT, Wu S and Zuo L. Nitric oxide in cancer metastasis. Cancer Lett. 2014; 353:1-7. | Article I PubMed Abstract | PubMed FullText

46. Hung WC, Wu TF, Ng SC, Lee YC, Shen HP, Yang SF and Wang PH. Involvement of endothelial nitric oxide synthase gene variants in the aggressiveness of uterine cervical cancer. J Cancer. 2019; 10:2594-2600. | Article | PubMed Abstract | PubMed FullText

47. Lee HJ, Song IC, Yun HJ, Jo DY and Kim S. CXC chemokines and chemokine receptors in gastric cancer: from basic findings towards therapeutic targeting. World J Gastroenterol. 2014; 20:1681-93. | Article | PubMed Abstract | PubMed FullText

48. Mantovani A, Savino B, Locati M, Zammataro L, Allavena P and Bonecchi $\mathrm{R}$. The chemokine system in cancer biology and therapy. Cytokine Growth Factor Rev. 2010; 21:27-39. | Article I PubMed

49. Samadi AK, Bilsland A, Georgakilas AG, Amedei A, Amin A, Bishayee A, Azmi AS, Lokeshwar BL, Grue B, Panis C, Boosani CS, Poudyal D, Stafforini DM, Bhakta D, Niccolai E, Guha G, Vasantha Rupasinghe HP, Fujii H, Honoki K, Mehta K, Aquilano K, Lowe L, Hofseth LJ, Ricciardiello L, Ciriolo MR, Singh N, Whelan RL, Chaturvedi R, Ashraf SS, Shantha Kumara HMC, Nowsheen S, Mohammed SI, Keith WN, Helferich WG and Yang X. A multi-targeted approach to suppress tumor-promoting inflammation.
Semin Cancer Biol. 2015; 35 Suppl:S151-S184. | Article | PubMed Abstract | PubMed FullText

50. Nickoloff BJ, Ben-Neriah Y and Pikarsky E. Inflammation and cancer: is the link as simple as we think? J Invest Dermatol. 2005; 124:x-xiv. | Article I PubMed

\section{Citation:}

Hussein AM, Darwish ZE and Soliman OH. Inflammation and cancer interconnection; simply as we think. Appl Sci Rep. 2020; 7:1.

http://dx.doi.org/10.7243/2054-9903-7-1 